\title{
СОВМЕСТИМОСТЬ ЭНТОМОФАГОВ С БИОЛОГИЧЕСКИМИ И БИОРАЦИОНАЛЬНЫМИ СРЕДСТВАМИ ЗАЩИТЫ РАСТЕНИЙ
}

\author{
И.С. АГАСЬЕВА, М.В. НЕФЕДОВА, Е.В. ФЕДОРЕНКО, А.О. МКРТЧЯН, \\ А.С. НАСТАСИЙ, В.Я. ИСМАИЛОВ
}

\begin{abstract}
Актуальность исследований чувствительности полезных энтомофагов к биологическим (полученным на основе живых агентов и продуктов их жизнедеятельности) и биорациональным (на основе выделенных из природных источников веществ и их синтетических аналогов) средствам защиты растений предопределена развитием технологий органического и экологизированного растениеводства. Применение традиционных инсектицидов вызывает массовую гибель хищных жужелиц, клопов, кокцинеллид, златоглазок, мух-сирфид и тахин, паразитических трихограмматид, ихневмонид, браконид и других полезных видов. Это приводит к слабо контролируемому развитию и размножению вредителей, формированию их резистентных популяций и увеличению пестицидной нагрузки на агроценозы. В представленной работы мы впервые определили лабораторную и полевую токсичность ряда российских и зарубежных препаратов, рекомендованных для применения на различных культурах, в отношении полезной энтомофауны агроценозов кукурузы, картофеля, яблони, гороха. Оригинальность исследования определяется подбором биопестицидов, позволяющим применять их интегрированно с энтомофагами в технологиях органического земледелия. Установлено, что биорациональные инсектициды Фитоверм ${ }^{\circledR}$ КЭ (концентрат эмульсии, норма расхода 1,3 л/га; «Фармбиомед», Россия), Vertimec ${ }^{\circledR}$ КЭ (норма расхода 1 л/га, «Syngenta AG», Швейцария), Atabrone ${ }^{\circledR}$ КC (конщентрат суспензии, норма расхода 0,75 л/га; «ISK Biosciences», Бельгия), высокоэффективные против вредных чешуекрылых и тлей на кукурузе, сое, горохе, не оказывали токсического влияния на массово применяемых энтомофагов габробракона (Habrobracon hebetor Say) и афидиуса (Aphidius matricaria Hal.). Полученные результаты также подтвердили возможность совместного применения хищных клопов подизуса (Podisus maculiventris Say) и периллюса (Perillus bioculatus Fabr.) с препаратами, разработанными против колорадского жука на пасленовых культурах. При использовании Битоксибациллина ${ }^{\circledR}$ П (порошок, норма расхода 4 кг/га; ПО «Сиббиофарм", Россия) и Фитоверма ${ }^{\circledR}$ КЭ (0,2 л/га) выживаемость имаго хищного клопа P. maculiventris достигала соответственно 88 и $82 \%$, личинок старшего возраста - 64\%, имаго хищного клопа P. bioculatus - 97 и $91 \%$, личинок IV-V возраста - 58 и $52 \%$. Фитоверм при норме расхода 1 л/га, рекомендуемой против тлей, не влияет на жизнеспособность афидофагов Cycloneda sangvinea Mul. и Harmonia axyridis Pallas на кукурузе, горохе и яблоне: выживаемость взрослых жуков C. sangvinea составила $85 \%$, H. axyridis - 88 \%. Результаты исследований могут быть использованы при разработке систем биологического и интегрированного контроля вредителей кукурузы (хлопковая совка, стеблевой кукурузный мотылек, кукурузная и злаковая тли), картофеля (колорадский жук, картофельная тля), гороха (гороховая тля), яблони (яблонная плодожорка, зеленая яблонная тля) в технологиях органического и экологического земледелия.
\end{abstract}

Ключевые слова: биологические препараты, энтомопатогены, чувствительность насекомых к пестицидам, энтомофаги, Habrobracon hebetor Say, Aphidius colemani Vier, Perillus bioculatus Fabr., Podisus maculiventris Say, Cycloneda sangvinea Mul., Harmonia axyridis Pallas.

За последние 16 лет органическое сельское хозяйство активно развивается во всем мире (площади увеличились в 4 раза, составив около $1 \%$ всех сельскохозяйственных земель сертифицировано более 2 млн производителей органической продукции, более $75 \%$ из них - в развивающихся странам (1-3). Стремление к развитию органического производства актуально более чем в 170 странах, и этот показатель ежегодно возрастает в связи с востребованностью такой продукции (4-7).

В органическом земледелии для контроля вредителей применяются препараты, полученные с использованием энтомопатогенных организмов, а также полезные хищные и паразитические насекомые, размноженные в биолабораториях (8-11). Заблаговременная интродукция искусственно выращенных энтомофагов позволяет повысить эффективность биологического контроля вредителей (12-14). Однако в полевых условиях нередко воз-

* Исследования выполнены согласно Государственному заданию № 075-00376-19-00 Министерства науки и высшего образования РФ в рамках НИР по теме № 0686-2019-0009. 
никают ситуации, когда природные энтомофаги не в состоянии самостоятельно сдерживать численность вредителя на хозяйственно неощутимом уровне. Причинами могут быть асинхронность фенологии фитофага и энтомофага или очень низкая численность последнего после перезимовки, что стимулирует неконтролируемое размножение вредных видов, но одной из главных считаются традиционные химические обработки, которые приводят к гибели полезной энтомофауны, но не влияют на численность фитофагов из-за сформировавшейся в их популяциях резистентности ко многим инсектицидам (15-18). В связи с этим возникает необходимость в применении биологических и биорациональных препаратов, которые бы не оказывали негативного воздействия на полезных членистоногих и дополнительных выпусках энтомофагов и акарифагов (19). Первая группа - это биологические средства борьбы с вредителями, возбудителями болезней растений и сорняками, полученные на основе живых микроорганизмов или продуктов их жизнедеятельности. Вторую составляют химических соединения или вещества природного происхождения, малотоксичные для теплокровных организмов (феромоны, эфирные и растительные масла, регуляторы роста и т.д.). Препараты обеих групп быстро разлагаются, максимально безопаснее для окружающей среды, чем другие средства, и не накапливаются в цепях питания.

В экологизированном земледелии пестицидная нагрузка должна быть снижена на 50-75 \% (приближена к разрешенной при интегрированной защите) и предпочтительно применение биорациональных препаратов (регуляторы роста и развития насекомых, пестициды, не оказывающие отрицательного воздействия на полезную энтомофауну и др.). В органическом земледелии используются толькобиологические и биорациональные препараты, а традиционные химические инсектициды полностью запрещены $(14,20,21)$.

При подборе средств защиты важно оценить их токсическое действие на полезные организмы $(22,23)$. Гибель полезных членистоногих наиболее ощутима в многолетних насаждениях (сады, виноградники), так как эти ценозы представлены большим числом видов фитофагов и комплексами их энтомофагов, играющих важную роль в регулировании численности первых. Установлено, что применение инсектицидов приводит к массовой гибели хищных жужелиц (Carabidae), клопов семейств Pentatomoidae, Nabidae, Anthocoridae, кокцинеллид (Coccinellidae), златоглазок (Chrysopidae), мух-сирфид (Syrphidae) и тахин (Tachinidae), трихограмматид (Trichogrammatidae), ихневмонид (Ichneumonidae), браконид (Braconidae) и других полезных видов. На посевах однолетних культур энтомофаги также представлены значительным числом видов (на озимой пшенице - до 200, горохе - 300). На 1 га картофельного поля обитает от 2000 до 3400 сирфид, более 720 хищных пауков, 2400-4800 жужелиц, которые практически все погибают при применении традиционных инсектицидов (24). Обработки посевов пшеницы инсектицидами против клопа вредная черепашка (Eurygaster integriceps Put.) негативно влияют на энтомофагов из семейств Carabidae, Coccinellidae и Scelionidae. Фунгициды и гербициды, как правило, воздействуют на энтомофагов в значительно меньшей степени, чем инсектицидами. Предпочтительны те биологические и биорациональные средства защиты, которые безопасные для энтомофагов и акарифагов (25). Выявлена разная токсичность для полезной энтомофауны биорациональных препаратов на основе тиаметоксама, хлорантранилипрола, тефлутрина, дифеноконазоа, флудиоксонила, тиаклоприда, имидаклоприда и их сочетаний (слаботоксичные, малоопасные и умеренно опасные) (26-28). Так, препа- 
раты Герольд ${ }^{\circledR}$ ВСК (водно-суспензионный концентрат, биорациональный препарат с содержанием дифлубензурона 240 г/л; ЗАО фирма «Август», Россия), Проклэйм ${ }^{\circledR}$ ВРГ (водорастворимые гранулы; Proclaim ${ }^{\circledR}$, биорациональный препарат с содержанием бензоата эмамектина 50 г/кг, «Syngenta

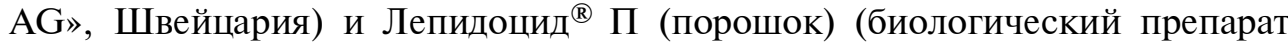
на основе споро-кристаллического комплекса Bacillus thuringiensis var. kurstaki, биологическая активность БА 3000 ЕА/мг, ПО «Сиббиофарм», Россия) не угнетают естественных энтомофагов сада - златоглазок, хищных клопов семейства Nabidae и жуков семейства Coccinelidae (29).

В настоящей работе впервые показана совместимость энтомофагов колорадского жука периллюса Perillus bioculatus Fabr. и подиуса Podisus maculiventris Say, эктопаразита хлопковой совки и других видов чешуекрылых Habrobracon hebetor Say, паразита тлей Aphidius colemani Vier, хищных кокцинеллид Cycloneda sangvinea Mul. и Harmonia axyridis Pallas с биологическими и биорациональными инсектицидами.

Цель исследования - определение чувствительности энтомофагов к биологическим и биорациональным средствам в рамках разработки систем биологической защиты сельскохозяйственных культур от вредителей.

Методика. Изучали действие биологических препаратов Битоксибациллин ${ }^{\circledR}$ П, Лепидоцид ${ }^{\circledR}$ CK (суспензионный концентрат, ПО «Сиббиофарм», Россия), Helicovex ${ }^{\circledR}$ CK («Andermatt Biocontrol AG», Швейцария), биорациональных препаратов Vertimec $^{\circledR}$ КЭ (концентрат эмульсии) и Ас$\operatorname{tara}^{\circledR}$ ВДГ (водно-диспергируемые гранулы) («Syngenta AG», Швейцария), Фитоверм ${ }^{\circledR}$ КЭ («Фармбиомед», Россия), Insegar ${ }^{\circledR}$ ВДГ и Atabron $^{\circledR}$ КС (концентрат суспензии, «ISK Bioscieces», Бельгия), а также химических инсектицидов Decis ${ }^{\circledR}$ Expert КЭ («Bayer AG», Германия), Coragen ${ }^{\circledR}$ KC («DuPont», США).

Совместимость биологических препаратов Битоксибациллин ${ }^{\circledR}$ П (норма расхода против чешуекрылых 4 кг/га, против тли 3 кг/га, против колорадского жука 3 кг/га), Лепидоцид ${ }^{\circledR}$ CK (против плодожорок 2 л/га, против тли 2 л/га), Helicovex ${ }^{\circledR}$ CK (против чешуекрылых 200 л/га) и биорациональных Vertimec ${ }^{\circledR}$ КЭ (против чешукрылых 1 л/га), Фитоверм ${ }^{\circledR}$ КС (против тлей 1,3 л/га, против колорадского жука 0,2 л/га), Coragen ${ }^{\circledR} \mathrm{KC}$ (против чешуекрылых 0,1 л/га), Insegar ${ }^{\circledR}$ ВДГ (протв чешуекрылых 0,6 кг/га), Atabron® КС (против чешуекрылых 0,75 л/га) с энтомофагами оценивали в лабораторных условиях - на коконах Habrobracon hebetor Say и злаковой тле, зараженной Aphidius colemani Vier., в полевых - на опытных делянках с посадками картофеля площадью 40 м² в 4-кратной повторности (для энтомофагов колорадского жука Perillus bioculatus Fabr. и Podisus maculiventris Say), в яблоневом саду площадью 4 га на 10 модельных деревьях, на кукурузе и горохе на делянках $50 \mathrm{~m}^{2}$ в 4-кратной повторности (для божьих коровок Cycloneda sangvinea Mul. и Harmonia axyridis Pallas).

При лабораторном культивировании габробракона насекомыми-хозяевами были гусеницы вощинной огневки (Galleria mellonela L.) средних возрастов. Гусениц помещали в стеклянные банки объемом 0,5 л и заражали паразитом. Банки затягивали бязевой салфеткой с ватным тампоном, смоченным $20 \%$ раствором сахара для подкормки энтомофага, и ставили в термостат (28-30 $\left.{ }^{\circ} \mathrm{C}\right)$. Через 7-8 сут после заражения образовывались коконы, которые в трижды обрабатывали препаратами, рекомендуемыми для защиты кукурузы от чешуекрылых вредителей. Использовали Битоксибациллин $^{\circledR}$ П (БА 1500 ЕА/мг, титр 20 млрд/г, норма расхода 4 кг/га), Лепидоцид ${ }^{\circledR}$ СК (БА 2000 ЕА/мг, титр 10 млрд/г, норма расхода 2 л/га); Vertimec $^{\circledR}$ КЭ (д.в. 18 г/л, норма расхода 1 л/га), Helicovex ${ }^{\circledR}$ CK $\left(7,5 \times 10^{12}\right.$ по- 
лиэдролов/л, норма расхода 200 мл/га), Insegar ${ }^{\circledR}$ ВДГ (норма расхода 0,6 Кг/га), Atabron ${ }^{\circledR}$ KC (норма расхода 0,75 л/га), Coragen ${ }^{\circledR}$ KC (норма расхода 0,1 л/г), Decis ${ }^{\circledR}$ Expert KЭ (норма расхода 0,1 л/га). Контрольные варианты обрабатывали дистиллированной водой.

Для размножения афидиуса использовали злаковую тлю (Schizaphis graminum Ron.), которую разводили на проростках пшеницы. На 3-4-е сут после инокуляции пшеницы злаковой тлей на растения помещали афидиусов $($ A colemani $)$, образовавшиеся мумии обрабатывали Фитовермом ${ }^{\circledR}$ КЭ (норма расхода 1,3 л/га), Лепидоцидом ${ }^{\circledR} \mathrm{CK}$ (норма расхода 2 л/га); Би-

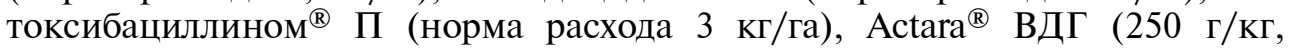
норма расхода 0,2 кг/га).

Токсичность средств защиты растений для хищных клопов и кокцинеллид в полевых условиях определяли для рекомендуемых против колорадского жука и тлей препаратов Фитоверм ${ }^{\circledR}$ КЭ (2 г/л, норма расхода соответственно 0,2 и 1,3 л/га) и Битоксибациллин ${ }^{\circledR}$ П (БА 1500 ЕА/мг, норма расхода 3 кг/га). Опытные делянки с энтомофагами, колорадским жуком и тлями обрабатывались рабочим раствором препаратов, используя ранцевый гидравлический опрыскиватель Pulverex (Швейцария). Численность хищных клопов и кокцинеллид учитывали до и после опрыскивания.

Статистическую обработку результатов проводили по общепринятой методике (30). В таблицах представлены средние $(M)$ и стандартные отклонения $( \pm \mathrm{SD})$. Расчеты выполняли с использованием программы Statistica 12.6 («StatSoft, Inc.», США). Статистическую значимость различий оценивали с помощью критерия Дункана при уровне вероятности $\mathrm{P}=95 \%$.

Результаты. Основные характеристики сравниваемых биологических и химических препаратов приведены в таблице 1.

1. Чувствительность эктопаразита Habrobracon hebetor Say к биологическим и химическим инсектицидам в лабораторном тесте $(M \pm \mathrm{SD})$

\begin{tabular}{|c|c|c|c|c|c|c|c|}
\hline \multirow{3}{*}{ Препарат, д.в. } & \multirow{3}{*}{$\begin{array}{l}\text { Расход, } \\
\text { л/га, } \\
\text { Кг/га }\end{array}$} & \multirow{3}{*}{$\begin{array}{l}\text { Коконов до } \\
\text { обработки, } \\
\text { шт. }\end{array}$} & \multicolumn{5}{|c|}{ Вылетело имаго } \\
\hline & & & \multicolumn{3}{|c|}{ по срокам учета, экз. } & \multirow{2}{*}{$\begin{array}{l}\text { всего, } \\
\text { эКз. }\end{array}$} & \multirow{2}{*}{$\begin{array}{l}\text { от исходно- } \\
\text { го числа, \% }\end{array}$} \\
\hline & & & 3-и сут & 5-e сут & 7-e cyт & & \\
\hline \multicolumn{8}{|c|}{ Би ологически е ин се ктициды } \\
\hline $\begin{array}{l}\text { Лепидоцид }{ }^{\circledR} \text { CK (Bacillus } \\
\text { thuringiensis var.kurstaki) }\end{array}$ & 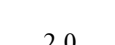 & 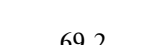 & 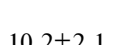 & $376+16$ & $74+18$ & & 798 \\
\hline Битоксибациллин ${ }^{\circledR}$ П (Bacillus & & & & & $1,+1,0$ & & \\
\hline thuringiensis var. thuringiensis) & 4,0 & 46,6 & $6,8 \pm 1,5$ & $19,3 \pm 3,4$ & $3,1 \pm 2,3$ & $29,2^{\mathrm{a}}$ & 62,7 \\
\hline Helicovex ${ }^{\circledR}$ CK (вирус ядерного & & & & & & & 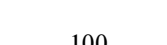 \\
\hline \multicolumn{8}{|c|}{ Биор а циональны е хим ически е инсектициды } \\
\hline Vertimec ${ }^{\circledR}$ КЭ (абамектин) & 1,0 & 64,0 & $9,6 \pm 2,4$ & $32,5 \pm 1,8$ & $4,5 \pm 1,1$ & $46,6^{\mathrm{bc}}$ & 72,8 \\
\hline Insegar ${ }^{\circledR}$ ВДГ (феноксикарб) & 0,6 & 80,3 & $14,7 \pm 1,5$ & $51,9 \pm 3,3$ & $12,4 \pm 1,1$ & $79,0^{\mathrm{c}}$ & 98,4 \\
\hline Atabron ${ }^{\circledR}$ КС (хлорфлуазурон) & 0,75 & 76,2 & $24,8 \pm 3,2$ & $44,3 \pm 1,3$ & $9,9 \pm 1,6$ & $76,2^{\mathrm{c}}$ & 100 \\
\hline \multicolumn{8}{|c|}{ Хим и чески е и нсе ектициды } \\
\hline Decis ${ }^{\circledR}$ Expert КЭ (дельтаметрин) & 0,1 & 87,5 & 0 & 0 & 0 & $0^{\mathrm{a}}$ & 0 \\
\hline Coragen ${ }^{\circledR}$ КС (хлорантранилипрол) & 0,1 & 91,0 & $22,5 \pm 2,2$ & $54,0 \pm 1,9$ & $14,5 \pm 3,1$ & $91,0^{\mathrm{ab}}$ & 100 \\
\hline Контроль & & 93,0 & $20,9 \pm 1,6$ & $56,2 \pm 4,2$ & $13,9 \pm 2,3$ & $93,0^{\mathrm{c}}$ & 100 \\
\hline $\begin{array}{l}\text { П р и м е ч а н и е. Между вариаң } \\
\text { нении в пределах столбца нет ста } \\
\text { ятности } \mathrm{P}=95 \%\end{array}$ & (4) & & & & ерию Д & & вне в \\
\hline
\end{tabular}

В лабораторном тесте (табл. 1) нормы расхода препаратов соответствовали рекомендованным для защиты кукурузы, сои, подсолнечника от хлопковой совки и других чешуекрылых вредителей. Выживаемость популяции эктопаразита габробракона после обработки биорациональным инсектицидом Vertimec ${ }^{\circledR}$ КЭ составила $72,8 \%$, биопрепаратами на основе Bacillus thuringiensis - 62,7 \% (Битоксибациллин ${ }^{\circledR}$ П) и 79,8\% (Лепидоцид $\left.{ }^{\circledR} \mathrm{CK}\right)$. Интересны данные по инсектициду Coragen ${ }^{\circledR} \mathrm{KC}$ : вылет имаго габробракона в тесте составил $100 \%$. Биопрепарат Helicovex ${ }^{\circledR}$ CK на основе вируса ядерного полиэдроза хлопковой совки оказался нетоксичным 
для $H$. hebetor (вылет имаго после обработки составил $100 \%$, что свидетельствует о полной совместимости энтомофага и вирусного препарата в системах биологической защиты кукурузы, сои, томатов от хлопковой совки). Наиболее угнетающее действие оказал препарат Decis ${ }^{\circledR}$ Expert: гибель эктопаразита составила $100 \%$.

В исследованиях американских ученых показано, что инсектициды на основе циантранилипрола, хлорантранилипрола, спинеторама, считающиеся экологически безопасными по сравнению с карбаматными препаратами проявляли негативное воздействие на развитие Chrysoperla carnea Stephens (Neuroptera: Chrysopidae) и Trioxys pallidus Haliday (Hymenoptera: Braconidae) (31).

2. Чувствительность паразита Aphidius colemani Vier. к биологическим и химическим инсектищидам в лабораторном тесте $(M \pm \mathrm{SD})$

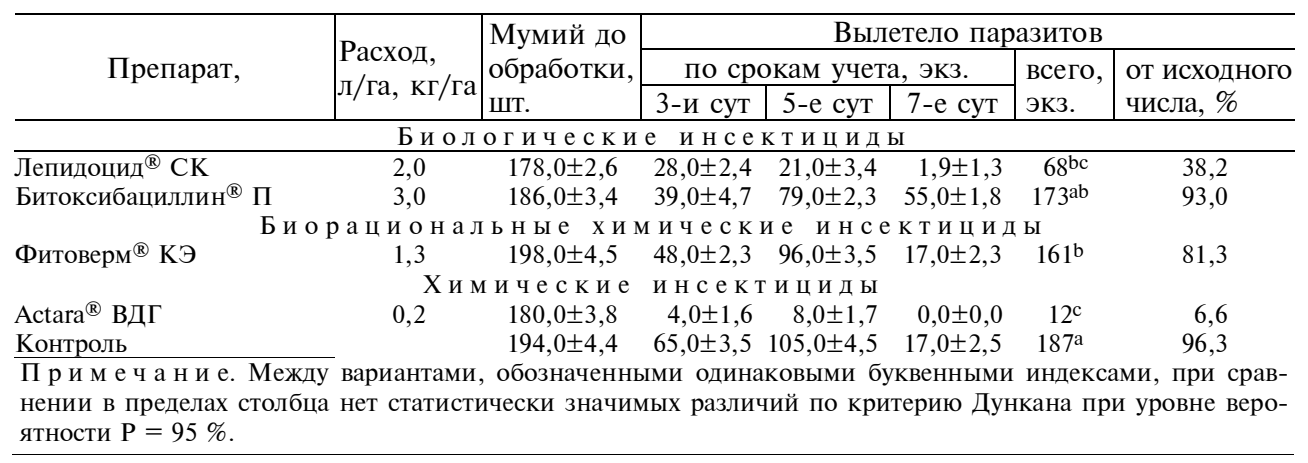

Оценка чувствительности паразита тлей A. colemani к биологическим и химическим препаратам, рекомендованным для защиты озимой пшеницы, плодовых и овощных культур от тлей, показала высокое сохранение жизнеспособности насекомых в вариантах с Фитовермом ${ }^{\circledR}$ КЭ и Битоксибациллином ${ }^{\circledR}$ П (табл. 2). При использовании препарата Actara ${ }^{\circledR}$ ВДГ только 12 особей афидиуса вылетели из 180 мумий. В исследованиях российских ученых также установлено, что биологические препараты Битоксибациллин ${ }^{\circledR}$ П и Лепидоцид ${ }^{\circledR}$ CK нетоксичны для афидофагов златоглазок, кокцинеллид и клопов-мирид (29).

3. Чувствительность клопов-азопин к биологическим и химическому инсектицидам $(M \pm \mathrm{SD}$, опытный участок ВНИИБЗР, г. Краснодар, 2015 год)

\begin{tabular}{|c|c|c|c|}
\hline \multirow{2}{*}{$\begin{array}{l}\text { Расход, } \\
\text { л/га, кг/га }\end{array}$} & \multirow{2}{*}{ Стадия развития насекомых } & \multicolumn{2}{|c|}{ Выживаемость насекомых на 7-е сут, \% } \\
\hline & & Podisus maculiventris Say & Perillus bioculatus Fabr. \\
\hline \multicolumn{4}{|c|}{ Ф и т о в е р м ${ }^{\circledR} \mathrm{КЭ,} 2$ г/л } \\
\hline \multirow[t]{3}{*}{0,2} & Имаго & $81,8 \pm 0,10^{\mathrm{cd}^{*}}$ & $90,9 \pm 0,10^{\mathrm{b}}$ \\
\hline & Личинки старшего возраста (III-IV) & $63,6 \pm 0,10^{\mathrm{c}}$ & $51,5 \pm 0,12^{\mathrm{a}}$ \\
\hline & Личинки младшего возраста (I-II) & $24,2 \pm 0,06^{a}$ & $0,0 \pm 0,00^{\mathrm{a}}$ \\
\hline \multicolumn{4}{|c|}{ Б и т о к с и б а ц и л л и н ${ }^{\circledR}$ П, биологическая активность 1500 ЕА/мг } \\
\hline \multirow[t]{3}{*}{3,0} & Имаго & $87,9 \pm 0,12^{\text {bd }}$ & $97,0 \pm 0,06^{\mathrm{b}}$ \\
\hline & Личинки старшего возраста (III-IV) & $63,6 \pm 0,10^{\mathrm{c}}$ & $57,6 \pm 0,16^{\mathrm{ac}}$ \\
\hline & Личинки младшего возраста (I-II) & $27,3 \pm 0,10^{\mathrm{a}}$ & $3,0 \pm 0,65^{\mathrm{a}}$ \\
\hline \multicolumn{4}{|c|}{ Actara ${ }^{\circledR}$ ВДГ, 250 г/кг } \\
\hline \multirow[t]{3}{*}{0,2} & Имаго & $0 \pm 0,0^{\mathrm{a}}$ & $0 \pm 0,0^{\mathrm{a}}$ \\
\hline & Личинки старшего возраста (III-IV) & $0 \pm 0,0^{\mathrm{a}}$ & $0 \pm 0,0^{\mathrm{a}}$ \\
\hline & Личинки младшего возраста (I-II) & $0 \pm 0,0^{\mathrm{a}}$ & $0 \pm 0,0^{\mathrm{a}}$ \\
\hline \multicolumn{4}{|c|}{ Контроль } \\
\hline \multirow[t]{3}{*}{0} & Имаго & $97,0 \pm 0,06^{\mathrm{b}}$ & $93,9 \pm 0,06^{\mathrm{b}}$ \\
\hline & Личинки старшего возраста (III-IV) & $93,9 \pm 0,12^{b}$ & $87,9 \pm 0,12^{\mathrm{bc}}$ \\
\hline & Личинки младшего возраста (I-II) & $97,0 \pm 0,06^{\mathrm{b}}$ & $97,0 \pm 0,06^{\mathrm{b}}$ \\
\hline
\end{tabular}

В полевых тестах на посадках картофеля определили чувствитель- 
ность хищных клопов $P$. maculiventris и $P$. bioculatus к препаратам Фитоверм $^{\circledR}$ КЭ и Битоксибациллин ${ }^{\circledR}$ П (табл. 3). Препараты испытывали в нормах, рекомендуемых против колорадского жука. В качестве химического эталона использовали препарат $\operatorname{Actara}^{\circledR}$ ВДГ. Эксперименты, проведенные в полевых условиях на делянках картофеля, показали, что препарат Фитоверм ${ }^{\circledR}$ КЭ в дозе 0,4 л/га оказывает токсическое действие на личиночные стадии хищных клопов, так на 7-е сут выживаемость личинок $P$. maculiventris I-II возраста резко снизилась, P. bioculatus - составила 0 \%. Имаго хищных клопов оказались менее чувствительными к действию препарата: выживаемость подизуса достигала 81,8 \%, периллюса $90,9 \%$. Битоксибациллин ${ }^{\circledR}$ П тоже не проявлял токсического действия на имаго хищных клопов (выживаемость подизуса - 87,9 \%, периллюса 97,0 \% (см. табл. 3).

В яблоневом саду, на кукурузе и горохе биорациональный препарат Фитоверм ${ }^{\circledR}$ КЭ в дозе 1,3 л/га не влиял на жизнеспособность афидофагов C. sangvinea и H. axyridis. Выживаемость имаго циклонеды составила 85,0 \%, хармонии - 87,7 \%. Личинки старших возрастов у обоих видов были устойчивыми к препарату, личинки младшего возраста $C$. sangvinea полностью погибли на 7-е сут. После обработки яиц происходило отрождение личинок, а затем их полная (100\%) гибель при $100 \%$ выживаемости в контроле. Vertimec ${ }^{\circledR}$ КЭ оказался нетоксичным для афидофагов. В качестве эталона применяли препарат Actara ${ }^{\circledR}$ ВДГ, который вызывал $100 \%$ гибели насекомых. Фитоверм ${ }^{\circledR}$ КЭ был токсичен для младших возрастов личинок хищных клопов и кокцинеллид, а Битоксибациллин ${ }^{\circledR} \Pi$ и Vertimec $^{\circledR}$ КЭ позволяли сохранять основной запас энтомофагов. Аналогичные результаты были получены при испытании биологического пестицида АқKөbelek ${ }^{\mathrm{TM}}$ (на основе Bacillus thuringiensis var. kurstaki) против вредителей люцерны, сои, кукурузы в юго-восточном Казахстане, который не проявил токсичности для кокциннеллид, браконид, хищных клопов семейств Nabidae и Miridae (32).

Таким образом, выполненное исследование показало, что для защиты кукурузы от хлопковой совки, кукурузного мотылька и черной кукурузной тли, яблони и гороха от тлей по органическим технологиям могут применяться биопрепараты Helicovex ${ }^{\circledR}$ CK, Битоксибациллин ${ }^{\circledR}$ П, Лепидоцид ${ }^{\circledR} \mathrm{CK}$ и биорациональные пестициды Vertimec ${ }^{\circledR}$ КЭ, Фитоверм КЭ совместно с энтомофагами габробраконом, афидиусом и божьими коровками. Препараты Coragen ${ }^{\circledR} \mathrm{KC}$, Insegar ${ }^{\circledR}$ ВДГ и Atabron ${ }^{\circledR}$ КС рекомендуются для экологизированного земледелия, так как они не оказывают угнетающего действия на агроценоз и могут использоваться как совместно с выпусками энтомофагов, так и самостоятельно. Бирациональные препараты Фитоверм ${ }^{\circledR} \mathrm{K} Э$, Vertimec ${ }^{\circledR}$ КЭ, рекомендуемые производителями для защиты картофеля от колорадского жука и сосущих вредителей, совместимы с хищными клопами и кокцинеллидами. Результаты этих исследований используются при подборе сочетаний биологических, биоактивных препаратов и энтомофагов для эффективного контроля вредителей в технологиях органического и экологического земледелия. 


\title{
COMPATIBILITY OF ENTOMOPHAGES WITH BIOLOGICAL AND BIORATIONAL PESTICIDES
}

\author{
I.S. Agas'eva, M.V. Nefedova, E.V. Fedorenko, A.O. Mkrtchyan, A.S. Nastasii, \\ V.Ya. Ismailov
}

\begin{abstract}
All-Russian Research Institute of Biological Plant Protection, PO box 39, Krasnodar, 350039 Russia, e-mail agasieva5@yandex.ru, dollkaSneba@yandex.ru, ms.fedor1960@mail.ru, mialusker22@gmail.com, nastasy.anton@yandex.ru, vlyaism@yandex.ru ( $\triangle$ corresponding author)
\end{abstract} ORCID:

Agas'eva I.S. orcid.org/0000-0002-1216-1106

Nefedova M.V. orcid.org/0000-0001-5390-233X

Fedorenko E.V. orcid.org/0000-0003-4411-626X

Mkrtchyan A.O. orcid.org/0000-0002-3252-9780

The authors declare no conflict of interests

Nastasii A.S. orcid.org/0000-0001-8324-0058

Ismailov V.Ya. orcid.org/0000-0002-6713-0059

Acknowledgements:

This work was carried out in accordance with the State Task No. 075-00376-19-00 of the Ministry of Science and Higher Education of the Russian Federation in the framework of the researches on subject No. 0686-2019-0009

Received June 5, 2018 doi: 10.15389/agrobiology.2019.1.101eng

\section{Abstract}

Severe adverse effects of chemical pesticides have driven demand for ecologically friendly technologies of plant growing with alternative pest control tactics. Traditional insecticides cause massive death of predatory ground beetles, bedbugs, coccinellids, lizards, flies and tachinid flies, parasitic trichogrammatids, ichneumonids, braconids and other useful species. Harmonized biological and chemical controls are becoming more relevant, which should include the use of beneficial entomofauna. This necessitates more data on sensitivity of entomophages to biologicals, biorational pesticides (i.e. natural substances and their synthetic analogues) and other selective chemistries. In this work, for the first time, we determined laboratory and field toxicity of several Russian and foreign conventional biologicals and chemicals for beneficial entomofauna of corn, potato and apple-tree agrocenoses. The originality of this study lies in its focus on searching commonly used biopesticides which can be integrated with entomophages in organic farming technology. The obtained data indicate that biorational insecticides Fitoverm ${ }^{\circledR}$ EC (emulsion concentrate) (Pharmbiomed, Russia, 1.3 1/ha), Vertimek ${ }^{\circledR}$ EC (Syngenta AG, Switzerland, 1.0 l/ha) and Atabron ${ }^{\circledR}$ SC (suspension concentrate) (ISK Biosciences, Belgium, $0.75 \mathrm{l} / \mathrm{ha}$ ) are highly effective against harmful lepidopterans and aphids on corn, soy and pea crops without toxic effect on the massively used entomophagous Habrobracon hebetor Say and Aphidius matricaria Hal. Our findings also indicate effectiveness of combination of predatory bugs podisus (Podisus maculiventris Say) and perillus (Perillus bioculatus Fabr.) with biologicals against Colorado beetle on solanaceous crops. In using Bitoxybacillin ${ }^{\circledR} P$ P (powder) (Sibbiopharm, Russia, $4 \mathrm{~kg} / \mathrm{ha}$ ) and Fitoverm ${ }^{\circledR}$ EC $(1.3 \mathrm{l} / \mathrm{ha})$, the survival rates of $P$. masculentris imagoes were $88 \%$ and $82 \%$, respectively, with $64 \%$ for older larvae. When using the same pesticides, the survival rates of $P$. bioculatus imagoes were $97 \%$ and $91 \%$, respectively, with $58 \%$ and $52 \%$ for fourth- to fifth-instar larvae. Fitoverm ${ }^{\circledR}$ at $11 /$ ha rate recommended against aphids does not affect the viability of the aphidophages Cycloneda sangvinea Mul. and Harmonia axyridis Pallas on maize, vegetable pea and apple, and allows for survival of $85 \%$ adult beetles $C$. sangvinea and of $88 \%$ Asian ladybeetles $H$. $a x$ yridis. These data can be used in protocols for co-application of biologicals, biorational preparations and entomophages in organic and ecological farming to effectively control pests of maize (cotton moth, corn stalk moth, corn and cereal aphids), potatoes (Colorado potato beetle, potato aphids), peas (leguminous aphis), and apple trees (apple moth, Apple green aphid).

Keywords: biological preparations, entomopathogenic, insect sensitivity to pesticides, $\mathrm{Ha}$ brobracon hebetor Say, Aphidius matricaria Hal., Perillus bioculatus Fabr., Podisus maculiventris Say, Cycloneda sangvinea Mul., Harmonia axyridis Pallas.

\section{REFEREN CES}

1. Rigby D., Cáceres D. Organic farming and the sustainability of agricultural systems. Agricultural Systems, 2001, 68(1): 21-40 (doi: 10.1016/S0308-521X(00)00060-3).

2. Bengtsson J., Ahnstrom J., Weibull A.C. The effects of organic agriculture on biodiversity and abundance: a meta-analysis. Journal of Applied Ecology, 2005, 42(2): 261-269 (doi: 10.1111/j.13652664.2005.01005.x).

3. Darnhofer I., Lindenthal T., Bartel-Kratochvil R., Zollitsch W. Conventionalisation of organic farming practices: from structural criteria towards an assessment based on organic principles: a review. Agron. Sustain. Dev., 2011, 30(1): 67-81 (doi: 10.1051/agro/2009011).

4. Ratnadass A., Fernandes P., Avelino J., Habib R. Plant species diversity for sustainable man- 
agement of crop pests and diseases in agroecosystems: a review. Agron. Sustain. Dev., 2012, 32(1): 273-303 (doi: 10.1007/s13593-011-0022-4).

5. Malézieux E. Designing cropping systems from nature. Agron. Sustain. Dev., 2012, 32(1): 15-29 (doi: 10.1007/s13593-011-0027-z).

6. Badgley C., Moghtader J., Quintero E., Zakem E., Chappell M.J., Avilés-Vázquez K., Samulon A., Perfecto I. Organic agriculture and the global food supply. Renewable Agriculture and Food Systems, 2007, 22(2): 86-108 (doi: 10.1017/S1742170507001640).

7. Argyropoulos C., Tsiafouli M.A., Sgardelis S.P., Pantis J.D. Organic farming without organic products. Land Use Policy, 2013, 32: 324-328 (doi: 10.1016/j.landusepol.2012.11.008).

8. Agas'eva I.S., Ismailov V.Ya. Trudy Kubanskogo gosudarstvennogo agrarnogo universiteta, 2016, 58: 67-74 (in Russ.).

9. Vazquez L.L., Perez N. El control biolygico integrado al manejo territorial de plagas de insectos en Cuba. Agroecología, 2017, 12(1): 39-46.

10. Ismailov V.Ya., Agas'eva I.S., Kil' V.I., Fedorenko E.V., Besedina E.N., Nefedova M.V. Nauka Kubani, 2017, 4: 26-33 (in Russ.).

11. Agas'eva I.S., Nefedova M.V., Fedorenko E.V., Umarova A.O. Mezhdunarodnyi nauchnoissledovatel'skii zhurnal, 2017, 7(61), ch. 2: 6-8 (doi: 10.23670/IRJ.2017.61.079) (in Russ.).

12. Kashutina E.V., Ignat'eva T.N., Kheishkho I.V. Subtropicheskoe $i$ dekorativnoe sadovodstvo, 2013, 48: 231-236 (in Russ.).

13. Prishchepenko E.A., Zanina L.N. Vestnik GBU Nauchnyi tsentr bezopasnosti zhiznedeyatel'nosti, 2015, 1(23): 121-125 (in Russ.).

14. Agas'eva I.S., Ismailov V.Ya. Trudy Kubanskogo gosudarstvennogo agrarnogo universiteta, 2017, 65: 53-59 (doi: 10.21515/1999-1703-65-53-59) (in Russ.).

15. Terekhov V.I., Ismailov V.Ya., Volkova G.V., Begunov I.I., Kovalenkov V.G., Tyurina N.D., Kazadaeva S.V., Fedorenkov V.I. Doklady Rossiiskoi akademii sel'skokhozyaistvennykh nauk, 2006, 6: 16-18 (in Russ.).

16. Kovalenkov V.G. Agrokhimiya, 2007, 8: 48-57 (in Russ.).

17. Bass C., Denholm I., Williamson M.S., Nauen R. The global status of insect resistance to neonicotinoid insecticides. Pesticide Biochemistry and Physiology, 2015, 121: 78-87 (doi: 10.1016/j.pestbp.2015.04.004).

18. Rane R.V., Walsh T.K., Pearce S.L., Jermiin L.S., Gordon K.H., Richards S., Oakeshott J.G. Are feeding preferences and insecticide resistance associated with the size of detoxifying enzyme families in insect herbivores? Current Opinion in Insect Science, 2016, 13: $70-76$ (doi: 10.1016/j.cois.2015.12.001).

19. Listopadova E.S., Nefedova M.V., Agas'eva I.S. Mezhdunarodnyi nauchno-issledovatel'skii zhurnal, 2014, 2(21), ch. 2: 10-11 (in Russ.).

20. Collier R.H., Finch S., Davies G. Pest insect control in organically-produced crops of field vegetables. Mededelingen (Rijksuniversiteit te Gent. Fakulteit van de Landbouwkundige en Toegepaste Biologische Wetenschappen), 2001, 66(2a): 259-267.

21. Berestetskii A.O. Zashchita i karantin rastenii, 2017, 8: 9-1 (in Russ.).

22. Cahill J.F., Elle E., Smith G.R., Shore B.H. Disruption of belowground mutualism alters interactions between plants and their floral visitors. Ecology, 2008, 89(7): 1791-1801 (doi: 10.1890/070719.1).

23. Carmo E.L., Bueno A., Bueno R.C.O., Vieira S.S., Gobbi A.L., Vasco F.R. Seletividade de diferentes agrotyxicos usados na cultura da soja ao parasitoide de ovos Telenomus remus. Ciência Rural, 2009, 39(8): 2293-2300 (doi: 10.1590/S0103-84782009005000188).

24. Gruzdev G.S., Zinchenko V.A., Kalinin V.A., Slovtsov R.N., Gruzdev L.G. Khimicheskaya zashchita rastenii /Pod redaktsiei G.S. Gruzdeva [Chemicals for plant protection. G.S. Gruzdev (ed.)]. Moscow, 1987 (in Russ.).

25. Dolzhenko T.V., Dolzhenko O.V. AGRO XXI, 2013, 4-6: 28-30 (in Russ.).

26. Dolzhenko T.V., Kozlova E.G., Dolzhenko O.V. Rossiiskaya sel'skokhozyaistvennaya nauka, 2016, 2-3: 21-23 (in Russ.).

27. Matsuda K., Buckingham S.D., Kleier D., Rauh J.J., Grauso M., Sattelle D.B. Neonicotinoids: insecticides acting on insect nicotinic acetylcholine receptors. Trends in Pharmacological Sciences, 2001, 22(11): 573-580 (doi: 10.1016/S0165-6147(00)01820-4).

28. Tomizawa M., Casida J.E. Selective toxicity of neonicotinoids attributable to specificity of insect and mammalian nicotinic receptors. Annual Review of Entomology, 2003, 48: 339-364 (doi: 10.1146/annurev.ento.48.091801.112731).

29. Dolzhenko T.V., Belousova M.E., Shokhina M.V. Sadovodstvo i vinogradarstvo, 2016, 6: 2935 (doi: 10.18454/vstisp.2016.6.3914) (in Russ.).

30. Dospekhov B.A. Metodika polevogo opyta [Methods of field trials]. Moscow, 1985 (in Russ.).

31. Amarasekarea K.G., Shearer P.W., Mills N.J. Testing the selectivity of pesticide effects on natural enemies in laboratory bioassays. Biological Control, 2016, 102(C): 7-16 (doi: 
10.1016/j.biocontrol.2015.10.015).

32. Temreshev I.I., Esenbekova P.A., Sagitov A.O., Mukhamadiev N.S., Sarsenbaeva G.B., Ageenko A.V., Homziak J. Evaluation of the effect of locally produced biological pesticide (АқКөbel$\mathrm{ek}^{\mathrm{TM}}$ ) on biodiversity and abundance of beneficial insects in four forage crops in the Almaty region of Kazakhstan. International Journal of Environment, Agriculture and Biotechnology (IJEAB), 2018, 3(1): 072-091 (doi: 10.22161/ijeab/3.1.10). 